\title{
THE ROLE OF CIVIL RELIGION FORMING CIVIL SOCIETY THROUGH PRACTICING RELIGIOUS COMMENT
}

\author{
Agus Salim Nst \\ Fakultas Ushuluddin UIN Suska Riau \\ agus.salim.nst@uin-suska.ac.id
}

\begin{abstract}
Modern society requires the new symbol rituals development to create a solidarity in a pluralistic country such Indonesia. This is what sociologists called civil religion. Andrew Shauks stated that civil religion is not a true religion as existing religious practices; it did not compete with conventional traditions, but it is existing on it and break it bonds. The same idea also explained by Olaf Schuman that civil religion is not a religious source for someone where he gained his understanding of the identity and social obligations. It remains a resource is the existence of religion civil religion should not and could not be a substitute powerless religions. Civil religion is not like a religion and not a rival to the existing religions. Rather it part, it exist of religions and values and norms generated by them to ensure a life together that is sustainable and harmony in an pluralistic society situation to create society (civil society), an open society, egalitarian, and tolerant based on ethical values, moral transdental.
\end{abstract}

Keywords: Civil Religion, Civil Society, and Religion.

\section{Introduction}

Human religious world show plural phenomenon or pluralism. Pluralism is a fact that can not be denied, it may sunnatullah in the process of development and the spread of the human race. The reality of pluralism on the one hand is a beautiful mosaic, but on the other hand is a challenge for the religious world. It because contains potential conflict. Although religion has a unifying force, religion also has devise potential. Religious ambivalence impression can be seen from phenomenon of war and peace, as a result of logical and religious character that may encourage disagreement and conflict. These characteristics include the nature of religion spread (absolutisme) and burden of religion spread (expansionism). The relation among this character is a trigger factor and hyper religious conflicts.

Beside the theological factors relate to the religion doctrine above, the actual religious conflicts are also due to cultural factors, regarding the social, economic, and political. Religious is not only faced by plurality challenge but also modernist. As a logical reasonableness of human history which tends to be dynamic and progressive, modernity can not be circumvented. Modernity is as part of social infrastructure, the power of ratio become instrument to manage society to encourage a transition and religious principles from faith which metaphysical become a part of social system that is reality essence. This makes religion as subsystems in integrated social system.

The problem of modernity above refers to the thinking of Manfred Halpren who called, "Revolution modernization involves the 
transformation used to manage society in political, social, economic, intellectual, religious and psychology. ${ }^{1}$ Emile Durkheim as quoted by Michael S. Northcoott said: the function of religious is a bridge of a conflict and generate social solidarity, sustain communities when faced on challenges of survival threaten from other tribes, deviate or rebel from within the tribe itself, from natural disasters. Religion argue that members of a community through a common symbolic description concerning their position in the cosmos, history and their goals in right regulation. Religion is also permit forces or relationships which are built into the tribe.Therefore, religion is a source of social order and moral, bind members of society into a collective social project, a set of values and social goals.

Further Durkheim predicted that modern society will require the development of rituals and new symbols that can generate a sense of solidarity in the new Republicanism project. This is what sociologists called civil religion. Civil religion is religion as an attitude of citizens, civil religion is not to shift the position of religions and believed by citizen in a country, but civil religion is religious given the importance of the public to be directed to the love of responsibility, either as citizens or adherent, and civil sentiments formation is sociability, they may not be a good citizen or confidence. Therefore, According to the religious comment of adherent in a country, civil society create modernists product.

\section{Plural, Civil Religion and Civil Society}

\section{Plural}

Before discussing the concept of Civil Religion, Civil Society and Civil Religion's role in the formation of civil society, it will be discussed plural or pluralism first. Because civil religion can be developed in a country where there

${ }^{1}$ Manfred Halpern, "Toward Further Modernization of The Study of New Nations”, in World Politics 17 (1964): 173. are many religions recognized such as Indonesia. In other words, if a country based berafeliasi in a particular religion, such as Roma, Saudi Arabia, Kuwait, Iran, and others, it can be said civil religion will not be developed.

Indeed plurality as it has been understood is the diversity, it meant the plurality in a country such tribe, nation, culture, and religion. There are five reasons why pluralism is always discussed by clergy, civilians, artists, politicians, scholars, students and others. first, all religions teach and spread peace in human life; second, the discourse of pluralist, tolerant and inclusive is an integral part of the religion, and inclusive spirit is God's law (sunatullah) can not be changed, thwarted, and covered. Therefore, pluralism should be developed in wider community. It is not for anyone but for the ideals of religion itself, which is a life full of love and affection between human beings; Third, there is a gap between the ideals of religious and empirical reality of religious life in the community; Fourth, the strengthening tendency exclusive and partly religious tolerance; Fifth, efforts need to be sought to address the problems associated with harmony and peace among peoples.

Etymologically, religious pluralism is derived from two words: "pluralism" and "religion". In Arabic translated "al-ta'addudiyyah al-diniyyah" and in English called "religious pluralism". Because of this term is derived from the English, It will be defined from English dictionary. Pluralism means "plural" or more than one. Second, "philosophical" means a thought recognizes the fundamental premise more than one. Third, "socio-political" is a system recognizes coexistence group diverse, such patterned, tribal, sect or parties to demonstrate high diversity aspect which very characteristic among them. Three of definitions above can be simplified in one definition, the co-existence of various groups or beliefs at any one time must be maintaining the differences and characteristics of each. 
There are three approaches to define religious. They are "function", "institution" and "substance". social history tend to define religion as an historical institution, a view of life that is institutionalized are easily distinguished between Buddhism and Islam by just looking at the historical background and differences in social system, beliefs, rituals and ethics.

The experts of sociology and anthropology define religion in terms of social function, namely a system of binding human life in the units or social groups. While most theological experts, phenomenology and religion history sees religion from a substantial aspect, it is sacred. If it studied in depth, in fact these three approaches are not contradictory, but complementary and perfect, especially if you want religious pluralism is defined in accordance with objective reality.

According Nurcholish Madjid, pluralism is not only understood by saying that our society is pluralistic, diverse, consisting of various races and religions, which is actually only describe fragmentation impression. Pluralism may not only be understood as "negative goodness", to keep fanaticism at bay. Pluralism must be understood as "genuine engagement of diversities within the bonds of civility. Pluralism is a compulsion for salvation of mankind, by a mechanism and balances of result. $^{2}$

From the definition before, pluralism a necessity that inevitably, consciously or not will always be associated and in contact with all aspects of human life. Pluralism (religion) also is a law (sunatullah) in which human beings created by God is always advisable to do a positive interaction for the sake of mankind life on earth. In conducting the interactions, adherent is not only required to recognize the existence of other religions (co-existence), but widely, religious communities are able to interact positively with

${ }^{2}$ Nurcholish Madjid, Islam Agama Kemanusiaan; Membangun Tradisi dan Visi Baru Islam Indonesia (Jakarta: Paramadina, 1995). people of other faiths or (pro-existence). Therefore, pluralism (religion) is taken for granted, but all of them should be sought actively by all religious communities.

There are assumptions from groups argue that pluralism is something ridiculous. The group is worried that pluralism can lead to silting aqidah caused not feel proud of their own religion, besides the group also considered as "believes" that religious pluralism will be stuck on the syncretism. It is thought which seeks confounds and reconcile the different elements (perhaps contradictory) selected from religion and tradition, in a specific term or in the religions. Such concerns are certainly commendable, because religion is certainly not allowed to confound with the understanding that comes from other religions.

On the other hand, writer argue that a pluralist understand well in carrying the ideas of pluralism with all pluralism do not reach to what feared by opinion above (syncretism), because if someone is pluralist then in religious practice is stuck on syncretism, yet he has not called pluralistic. In this context, Alwi Shihab (doctor from 'Ain Shams Egypt University and Temple AS University) explained that religious pluralism is not relativism and syncretism. ${ }^{3}$

\section{Civil Religion}

Literally civil religion meant a civil religion (society), If It is seen as it is meant his religion. Therefore, it more accurately defined "civil diversity", because he does not have God, the holy book, apostles, pastors, monks and so on. Civil religion would strongly associated with a modern sociology that is American, Robert N. Bellah. In his case study, Bellah divided United States become a pluralist and democratic. In his observations, America developed religious civil, that is religion (diversity attitude) were not in favour of traditional religions (religions that

\footnotetext{
${ }^{3}$ Alwi Shihab, Islam Inklusif; Menuju Sikap Terbuka dalam Beragama (Bandung: Mizan, 1999).
} 
already exist and thrive in America) anything is embraced by an American citizen. The proof, according to Bellah is till now nobody American president who does not mention the name of God in an official speech State, and they mentioned God's religion or religious or traditional religion (such as Jesus Christ, and others). ${ }^{4}$

Even so, Bellah is not the first to launch a discourse, Jean-Jacques Rosseau is first introduced the concept of civil religion. In his opus magnum, On Social Contract, Rousseau divides religious into three, human religion and community's religious and odd religious. The first model by Rousseau described as a natural divine right or law (natural deity law), the second he called a civil or positive divine right or law (positive deity law). The third model, Rousseau describe this religion gives human two laws books, two heads of state, who wanted the opposite of their tasks, and prevent every person as well as citizens faith at the same time. In terms of political views, three types of religions have shortcomings.

Because of the three religions have weaknesses; Rousseau proposes fourth religion, that is religion civile, civil religion, compatible religion. Although it is not clear, Rousseau longed for a religion that will give inspiration to the people to defend their country such as defending their religion, positive part of citizens religious. Religion is uniting people in the feeling of social cohesion. It did not question their beliefs about the way to heaven; but it teaches how to live together with fellow citizens, whatever their religion.

Therefore, civil religion is more precisely defined as "an attitude of diversity owned by citizens", civil religion is not at all to shift the position of religion that already exist and are believed by the people in a country, but civil religion is that religious considering the importance of the public

${ }^{4}$ Robert N. Bellah, The Broken Covenant; American Civil Religion in Time of Trial, Second Edition (Chicago and London: The University of Chicago Press, 1992). to directed to "the love of his obligations" either as citizens or as religious, and civil sentiments since its formation is sociability, which apparently they are not likely to be a good citizen or a man of trust.

Therefore - hopefully - be understood, that civil religion means "diversity civilians (society) owned by various groups of religious communities, and - of course - do not have a god, scripture, apostle, or people who are considered sacred. God, scriptures etc are those owned and believed by existing religious communities. Moreover, it should remain a grip and a pride for each religious community. Therefore this concept (civil religion) will not make someone stuck or caught in a trap "Shirk" (polytheism). The concept of diversity is also-borrowing a phrase Mercea Eliade - will not permit the profane or otherwise. For example adherents (community) of Islam that God must be believed is Allah SWT along with assorted a legal requirement, as well as the followers of other religions, because religion have something called the Ultimate Reality or in term Paul Tillich called the Ultimate Concern or in terms Rudolf Otto called Mysterium tremendum.

Andrew Shanks insists that civil religion is not a true religion as existing religious practices; it did not compete with conventional traditions, but it is exist among them, and broke their bonds. ${ }^{5}$ The same view is also expressed by Olaf Schuman in book Beyond Belief (in Indonesia published) that civil religion is not a religious source for someone where he gained his understanding about identity and social obligations. The resource consistently is religions, and civil religion should not-and may not be powerless to-be a substitute for religion as a kind of "super religious". Further Schumann, civil religion is not super-religion, thus it is also not rival of existing religions. But substantially, it exists from religions, values and norms generated by them to ensure a sustainable

${ }^{5}$ Andrew Shanks, Agama Sipil, Alih Bahasa Yudi Santoso (Jakarta: Jalasutra, 2003). 
life together in an atmosphere of a pluralistic society. ${ }^{6}$

When civil religion discourse brought to the Indonesian context, then there will be questions that can be rolled out possible themes, and how to expose it. In the book of Varieties of Civil Religion by Robert N. Bellah and Phillip E. Hammond described some conditions that can lead to civil religion; 1) the condition of religious pluralism, which is not possible for one religion to be used by the entire community as a source general meaning, 2) however, people are faced with the need to attach a meaning in their activities, especially when the activity was associated with individuals from diverse backgrounds religious, 3 ) required a replacement system of meaning, and if found, those whose activity is facilitated by the system will tend to adore him. It seems like statement of Andrew Shanks that civil religion can develop in a world (read: state) pluralistic, where citizenship has grown very large. ${ }^{7}$

It seems that it is only possible civil religion can be developed in a country where there are a wide variety of religions recognized by the State such as Indonesia. In other words, if a statebased (berafeliasi) in a particular religion-such as Rome, Saudi Arabia, Kuwait, Iran,-then it can be said civil religion will not be developed. The diversity of Indonesian is a reality that must be accepted positively and creatively by all religious. If it can be run in synergy, this country will be respected by other countries because the development will run optimally without being interrupted by inter-religious conflict. Therefore, harmony is one of the modal in development.

Diana Eck, a heroine in the management of the world Council of Churches in Geneva

${ }^{6}$ Olaf Schumann, 'Bellah dan Wacana 'Civil Religion' di Indonesia" Kata Pengantar Edisi Indonesia, dalam Robert N. Bellah, Beyond Belief; Esei-esei tentang Agama di Dunia Modern (Jakarta: Paramadina, 2000).

${ }^{7}$ Robert N. Bellah and Phillip E. Hammond, Varietes of Civil Religion (San Francisco: Harper \& Row Publishers, 1980).
Switzerland argues the notion of pluralism is not same as the plurality. Pluralism refers to the existence of interdependent relationships between different things, while diversity refers to the absence of such a relationship between different things. Thus, it can be understood that pluralism means the existence of a mutual dependence relationship among people, therefore there is no terms of domination, hegemony, cooptation and so on, because all of them have togetherness sense, it is called interrelatedness of dependent relationship or plural society with different dimensions.

Back to the first discussion that harmony is a capital for development. According to Marshall, quoted by Syamsul Arifin, he expanded the scope of using capital concept is abysmal economic boundaries. Beside the capital in a material sense, humans also need others capital, namely social and spiritual capital. Social capital is the wealth making communities and organizations have function effectively for common interest. The spiritual capital is an essential dimension giving a sense of meaningful in human life to be more meaningful substantially. Although the social and spiritual capital are not in the form of goods, in economic sense, said Marshall, but it should not be deemed having no economic benefits. Social capital gave benefits broader than economics. Thus, other capitals which exist in a community need to be synergized with social capital.

Therefore, it can be understood that in developing a country is not only requires economic capital but also social capital and spiritual capital. It is support in moral from society which is actually a religious society. This support may only be obtained if society felt safe, tranquil, peaceful and living in harmony atmosphere.

Indonesia on the basis of the State (Philosophische Grondslag) namely Pancasila is the result of formulation of founding fathers certainly very open to develop civil religion discourse. According to historical aspect, the consciousness of the founding fathers would 
be the diversity of the Indonesian nation admirable, as far in advance they are already thinking about how to accommodate all the interests which come from a variety of nationalities especially from a variety of religions.

Komaruddin Hidayat stressed, morally and politically we deserve all respect and continue the vision of the Founding Fathers who from the beginning has laid the State ideology (Pancasila) based on religious humanist spirit. Their commitment to respect values of religious and humanity are developed in locus Indonesian is clear evidence. Since the beginning this nation has indeed stepped up and made anticipation, the presence of a pluralistic global society bound by the principles of humanity and divinity. ${ }^{8}$

\section{Civil Society}

The concept of civil society is a translation or Islamic terms of civil society concept that was first launched by Dato Seri Anwar Ibrahim in his speech on national symposium in a scientific forum at Festival Istiqlal, September 26, 1995 in Jakarta. Understanding of civil society as civil society refers to the concepts and forms of civil society in the hands of Prophet Muhammad. Medina community is regarded as a historical legitimacy innocence formation of civil society in modern Muslim societies. Concept proposed by Anwar Ibrahim is going to show that the ideal society is a society that has advanced civilization. Moreover, $\mathrm{He}$ mentioned that civil society is a fertile social system based on moral principles assures the balance between individual freedom and society stability.

The concept of civil society came and developed from the historical of struggle of the people/cicero is Westerners who first used the word of "societas civilis" in his political

${ }^{8}$ Komaruddin Hidayat, Wahyu di Langit, Wahyu di Bumi; Doktrin dan Peradaban Islam di Panggung Sejarah (Jakarta: Paramadina, 2003). philosophy, the concept of civil society was first conceived as a state. Historically, the term of civil society is from the thought of Monteque, J.J. Rousseau, John Locke and Hubbes. The three men began to organize a civil society which capable melt-authoritarian monarchy absolute power and church orthodoxy. ${ }^{9}$

Between Masyarakat Madani and Civil Society as stated above, civil society is the term to translate out concept be "Islamic". Judging from the substance of civil society and compares the Madinah society that is used as a justification for forming civil society in modern Muslim societies will be found equality and difference among them.

Another difference between Masyarakat Madani and civil society is a civil society is the product of modernity, while modernity is product of a movement Renaisme; secular society movements that marginalize God. So that civil society has a moral-transcendental fragile due to leave God. From this reason Ma'arif defines Masyarakat Madani as an open society, egalitarian and tolerant on the foundation of moral values transcendental ethics that comes from God's revelation.

Masyarakat Madani is a face concept: it has many meanings or often interpreted with different meanings. If refers to English language, it comes from the civil society, a contraposition of community military. Masyarakat Madani is a civilized society; respected human values, advanced in mastering of science and technology.

Referral to the Medina community as typical of ideal society, it is not in imitation of structure its society but on the properties adorn this ideal society. As implementation of commanding the good and forbidding the evil that is in line with the divine guidance, as well as association and unity. In order to build "Masyarakat Madani modern", emulate the

${ }^{9}$ Jean Jacques Rousseau, Kontrak Sosial, alih bahasa Sumardjo (Jakarta: Erlangga, 1986). 
Prophet Muhammad is not only the physical appearance alone, but also the attitude demonstrate by him when interact with fellow Muslims or with other people, such as keeping the unity of the Muslims, honour and do not underestimate other groups, to be fair to anyone, do not perform religious coercion, and other virtues.

We also need to emulate the attitude of Muslims were not a dichotomy between world life and hereafter. They did not leave world for afterlife and did not leave his world for hereafter. They are to be balanced (tawassuth) in pursuit of happiness of world and hereafter. If the attitude inherent in society is able to emulate Muslims of Medina at this time, so, the Islamic revival is only a matter of time.

The concept of civil society is a notion describes a civilized society which refers to virtues by developing and applying social interaction principles that is conducive to the creation of democracy order in society and state.

\section{The Role of Civil Religion Forming of Civil Society}

Based on the discussion of civil religion concept above, it can be understood that a large contribution of civil religion in forming civil society. Civil religion "civil diversity" (society) is not a true religion as exist religious practice; and civil religion also does not compete with conventional traditions, but it is exist between it all and break their bonds. Civil religion is not a religious source for someone where he gained his understanding about identity and social obligations. Source is fixed that the religious affiliation of each. Civil religion is not kind of super-religion, it is also not a rival to the existing religions. But substantially civil religion exist from religions professed and the values and norms which is produced by them to guarantee of society life together in harmony and sustainable atmosphere.

civil society refers to Masyarakat Madani, it is ideal society, advanced civilization, fertile social systems based on to the moral principles ensure a balance between individuals freedom and society stability.

\section{Conclusion}

Based on the explanation above, it can be concluded as follows:

1. Literally Civil religion interpreted as civil religion (society), but if it is seen as a separate religion. Therefore, it is accurately defined "civil diversity", because it does not have God, the holy book, apostles, pastors, monks and so on.

2. Civil religion is not at all to shift the position of religion which is believed by society in all state, but civil religion is religious in view of the importance of the public to be directed to the love of its obligations, either as citizens or as religious and civil because of sentiments formation is sociability that they seem unlikely to be a good citizen or a man of trust.

3. Civil religion is not a true religion such as existing religious practices, and it also does not compete with conventional traditions, but it is exist among them, and broke their bonds.

4. Civil religion is not a religious source for one where he gained his understanding about identity, and the social obligations. The source is fixed from existing religions. Civil religious should not and could not empower to be a substitute for religion, not as a super-religion nor as rival exist religions. But substantially, it is exist from religions, values and norms generated by them to ensure a sustainable life together; safe and harmonious in a pluralistic society atmosphere.

5. The concept of Masyarakat Madani is a translation or Islamic, terms of civil society concept. Understanding of civil society as Masyarakat Madani refers to the concept and Madina communities built the Prophet Muhammad. Madina community is regarded as a historical legitimacy in the formation of civil society in modern Muslim societies 
and civil society is fertile social system based on moral principles that ensure a balance between individual freedom and society stability.

\section{Bibliography}

Alwi Shihab. Islam Inklusif; Menuju Sikap Terbuka dalam Beragama. Bandung: Mizan, 1999.

Anis Malik Thoha. Tren Pluralisme Agama; Tinjauan Kritis. Jakarta: Perspektif, 2007.

Bellah, Robert N. Esei-esei tentang Agama di Dunia Modern. Jakarta: Paramadina 2000. -. The Broken Covenant; American Civil Religion in Time of Trial. Second Edition. Chicago and London: The University of Chicago Press, 1992.

Bellah, Robert N. and Phillip E. Hammond. Varietes of Civil Religion. San Francisco: Harper \& Row Publishers, 1980.

Departemen Pendidikan dan Kebudayaan. Kamus Besar Bahasa Indonesia. Jakarta: Balai Pustaka, 1989.

Komaruddin Hidayat. Wahyu di Langit, Wahyu di Bumi; Doktrin dan Peradaban Islam di
Panggung Sejarah. Jakarta: Paramadina, 2003.

Northcott, Michael S. "Pendekatan Sosiologis". dalam Peter Conolly (ed.). Aneka Pendekatan Studi Agama. terj. Imam Khoiri. Yogyakarta: LKiS, 2002.

Nurcholish Madjid. Islam Agama Kemanusiaan; Membangun Tradisi dan Visi Baru Islam Indonesia. Jakarta: Paramadina, 1995. . Cendekiawan dan Religiusitas Masyarakat; Kolom-kolom di Tabloid Tekad. Jakarta: Paramadina, 1999.

- Cita-cita Politik Islam Era Reformasi. Jakarta: Paramadina, 1999.

Rousseau, Jean Jacques. Kontrak Sosial. alih bahasa Sumardjo. Jakarta: Erlangga, 1986.

Rumadi. "Agama dan Negara: Dilema Regulasi Kehidupan Beragama di Indonesia." dalam Istiqro’ 04, No. 01 (2005).

Schumann, Olaf. "Bellah dan Wacana 'Civil Religion' di Indonesia” Kata Pengantar Edisi Indonesia, dalam Robert N. Bellah. Beyond Belief; Esei-esei tentang Agama di Dunia Modern. Jakarta: Paramadina, 2000.

Shanks, Andrew. Agama Sipil. Alih Bahasa Yudi Santoso. Jakarta: Jalasutra, 2003. 